\title{
Os Peroneum 障害の治療経験
}

\author{
小 林 駿 介* 吉 村 一 朗* 金 澤 和 貴* \\ 萩 尾 友 宣* 山本 卓 明*
}

【はじめに】Os peroneum は長腓骨筋腱内に存在する過剩骨で，足部外側の疼痛の原因となることがあ る.今回，我々はOs peroneum と腓骨筋腱結節のインピンジメントにより発症したと思われる症例を経 験したので報告する。【症例】 64 歳男性. 以前より足関節の捻挫を繰り返していた。今回，特に誘引なく 右足関節外側部痛が出現．前医にて長腓骨筋腱内の過剩骨を指摘され，当科紹介受診。画像検查にてOs peroneum と腓骨筋腱結節とのインピンジメントによる障害と，陳旧性足関節外側勒带損傷の診断で，過 剩骨摘出術と外側勒带修復術を行い，術後良好な成績を示した。【考察】Os peroneumは骨折や骨壊死に より疼痛が出現することが多い。しかし，大きな Os peroneumの場合は腓骨筋腱結節とのインピンジメ ントが疼痛の原因となることがある。

Key words: Os peroneum (Os peroneum), lateral midfoot pain (外側中足部痛), impingement (イン ピンジメント)

\section{は じめに}

Os peroneum は長腓骨筋腱内に存在する過剩骨で, 新鮮骨折, 疲労骨折, 骨軟骨炎などにより障害を生じ, 足部外側の疼痛の原因となる。今回我々は, Os peroneum と腓骨筋腱結節のインピンジメントにより発 症したと思われる症例を経験したので報告する。

\section{【症例】 64 歳男性}

【主訴】右足外側部痛

【現病歴】以前より足関節の捻挫を繰り返していた。今 回，特に誘引なく右足外側部痛が出現し，前医にて腓 骨筇腱内の過剩骨を指摘され当科紹介受診.

【現症】右足前外側に腫脹と腓骨筋腱結節付近に圧痛 を認めた，足関節の可動域は正常であったが，足関節 の前方動摇性を認めた. JSSF ankle-hind foot scale は 74 点であった。

【画像検查】単純 X 線検查の足部斜位像と踵骨軸写像 で踵骨外側前方に過剩骨を認めた（図 1)。単純 CT 検查では踵骨前外側に $28 \times 16 \mathrm{~mm}$ 大の過剩骨を認め た（図 2).3 D-CT 検查では長腓骨筋腱内に腓骨筋腱 結節に隣接する過剩骨が存在し, Os peroneum と考 えられた（図3)。MRI 検查では，腓骨筋結節部に STAR 像で高信号域を認め, Os peroneum と腓骨筋 腱結節のインピンジメントが示唆された。また，Os peroneum 自体には壊死や骨折を示唆する所見は認め
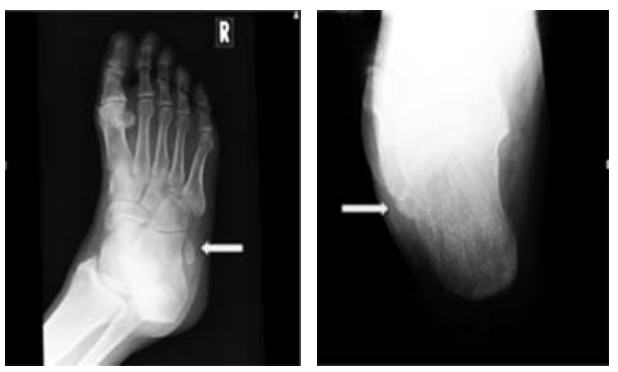

図 1

単純 X 線. 足部斜位像と踵骨軸写像では, 踵骨外側前 方に過剩骨を認める。
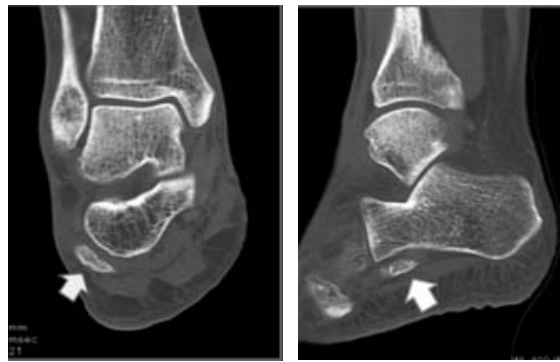

図 2

単純 CT 検査. 踵骨前外側に $28 \times 18 \mathrm{~mm}$ の過剩骨を認める.

られなかった（図4). 以上より, Os peroneum と腓 骨筋結節とのインピンジメントと，陳旧性足関節外側 勒帯損傷と診断した，疼痛が継続していることから過

$*$ 福岡大学医学部整形外科学教室 


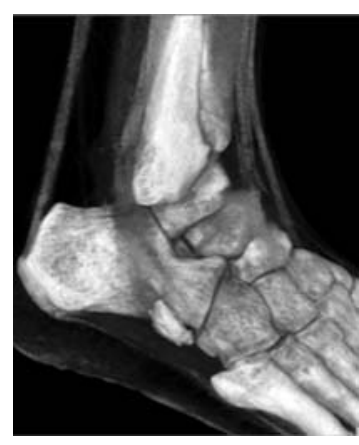

図 3

3 D-CT 検查. 長腓骨筋腱内で腓骨筋結節に隣接する過剩骨を 認める。
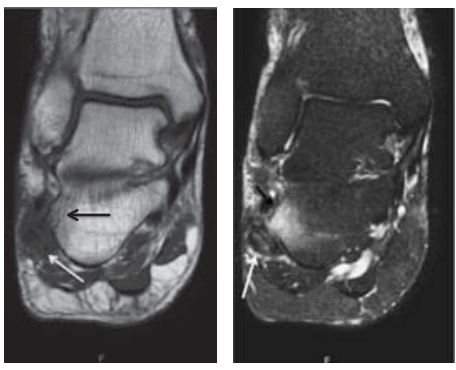

图 4

MRI 検査．腓骨筋腱結節部にSTIR 像で高信号域を認め, Os peroneum とのインピンジメントが示唆される (黒矢印)。ま た，Os peroneum に壊死や骨折を示唆する所見は認められな い(白矢印).

剩骨摘出術と外側勒带修復術を行う方針とした。 Os peroneum を核出する上で腓骨筋腱の再建が必要と判 断した場合は，半腱様筋腱を用いた再建術を行う方針 とした。

【手術所見】踵部外側の腓骨筋腱に沿って皮下を展 開すると，長腓骨筋腱内にOs peroneum を認めた (図 5)。また，Os peroneum の近位には腓骨筋腱結 節が存在していた。 Os peroneumを摘出しても，腓 骨筋腱線維は十分に温存できたため，再建術は行わな かった（図 6)。摘出によって生じた腱の縦断裂は連 続縫合し (図 7)，摘出したOs peroneum は $28 \times 16$ $\mathrm{mm}$ であった（図 8). 断裂していた足関節外側勒帯 は直視下でBrostom 法により修復を行った。

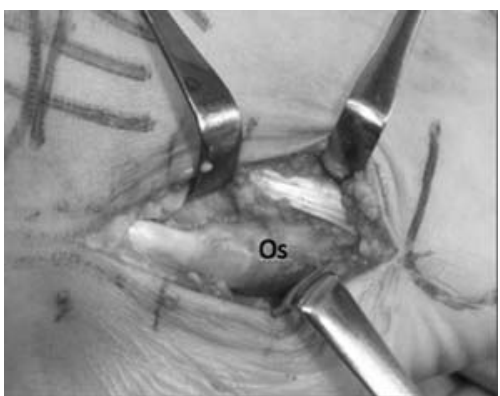

図 5

長腓骨筋腱内に Os peroneum を認め，近位には腓骨筋腱結節 を認める。

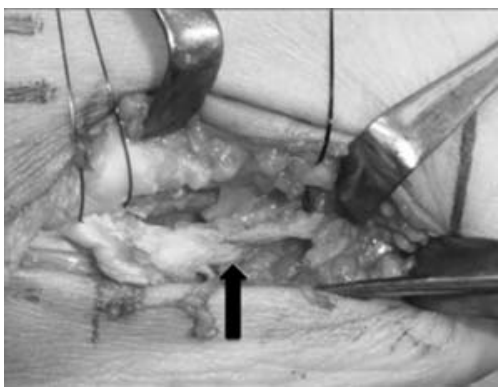

図 6

Os peroneum を摘出後，腓骨筋腱線維は十分に温存できた (黒矢印).

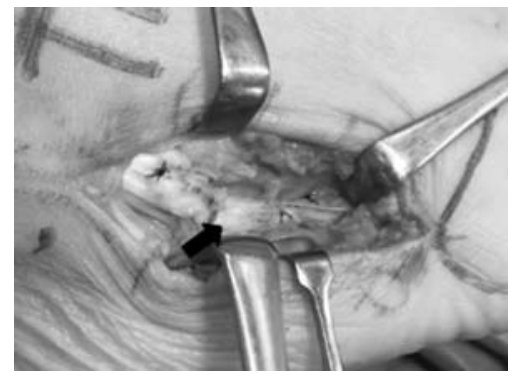

図 7

摘出の際に生じた腱の縦断裂は連続縫合を行った（黒矢印）.

【経過】後療法は, 術後 3 週間外固定とし， 2 週後よ り部分荷重歩行開始，術後 4 週目上り足関節可動域訓 練開始とした. 術後経過は, 術後 3 ケ月で JSSF anklehind foot scaleは 75 点から 95 点まで改善し, 術後 2 年経過した時点でも満足度は維持され腓骨筋力は正常 


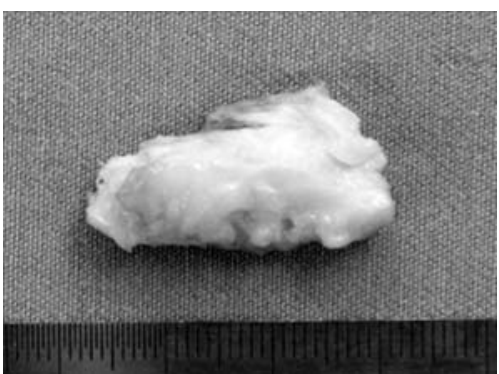

図 8

Os peroneum の大きさは $28 \times 16 \mathrm{~mm}$ であった

であった，画像検査に於いても，長腓骨筋腱内に存在 していた過剩骨は消失して㧍り，長腓骨筋腱の連続性 も良好であった（図 9).

\section{考察}

Os peroneumの本邦での出現頻度は $9 \%$ と比較的 まれで，我々が渉猟し得た範囲で 55 例であった (3) $^{3-5}$. 有痛性障害を起こす頻度は低く，発症の原因としては 機械的なストレスに伴う骨折や分裂によるものが多く 報告されている(12/4)577)。また，Os peroneum障害の手 術療法としては, Os peroneum を摘出し, 長腓骨筋 腱の損傷が大きい場合は再建術を要したと報告されて いる ${ }^{3 / 488}$. 腓骨筋腱結節の hypertrophy を伴う Os peroneum 障害を，過剩骨の摘出に加え，腓骨筋腱結節 の切除を施行し，良好な成績が報告されている6). 本 症例では, 腓骨筋腱結節の hypertrophy は認めらな かったため，摘出のみを行った。また，足関節の不安 定性が少なからず発症の要因と推察されたため, 足関 節外側勒带修復術を行った。

結語

腓骨筋腱結節とのインピンジメントにより発症した 症例を経験した。腓骨筋腱結節に明らかな hypertro-

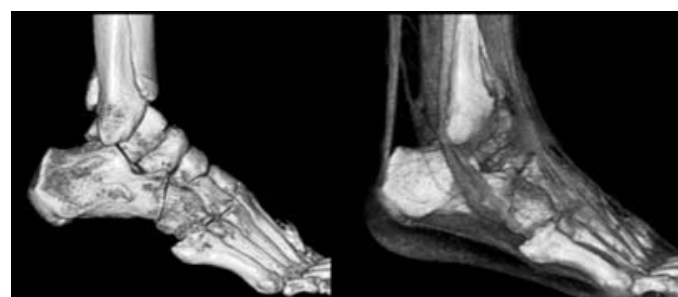

図 9

3 D-CT 検査では Os peroneum が完全に摘出されており，長 腓骨筋腱の連続性も保たれている。

phy を認めず，足関節外側勒帯修復術と Os peroneum 摘出術を施行し良好な成績を得られた。術後 2 年経過 した現在も，本人の満足度は高かった。

\section{参 考 文 献}

1) Bianchi, S., Bortolotto, C., Dragi, F.: Os peroneum imaging : normal appearance and pathological findings. Insights Imaging, 8: 59-68, 2017.

2) Bruce, W. D., Christofersen, M. R., Phillips, D. L. Stenosing tenosynovitis and impingement of the peroneal tendons associated with hypertrophy of the peroneal tunbercle. Foot Ankle Int., 20 (7) : 464-467, 1999.

3) Chagas-Neto, F. A., de Souze, B. N., Nogueira-Barbosa, M. H. : Painful os peroneum syndrome: underdiagnosed condition in the lateral midfoot pain. Case Rep. Radiol., 2016 : 8739362. doi : 10.1155/2016/8739362.

4）小林令奈ら：Os peroneum 障害の 3 例. 日足の外科会 誌，23(2)：122-127，2002.

5) Pierson, J., Inglis, A. E. : Stenosing tenosynovitis of the peroneus longus tendon associated with hypertrophy of the peroneal tubercle and an on os peroneum. A case report. J. Bone joint Surg. Am.,74 (3) : 440-442, 1992.

6) Sobel, M., et al.: Painful os peroneum syndrome:a spectrum of conditions responsible for plantar lateral foot pain. Foot Ankle Int., 15(3) : 112-124, 1994.

7）高岡孝典ら：Os peroneum 障害の治療経験. 日足の外 科会誌，22(2)：101-106，2001.

8）山口浩司ら：巨大な Os peroneumによる種子骨障害 の一例．整外と災外，49(4)：1050-1052,2000. 